\title{
KONSELING KELUARGA DENGAN HUMAN VALIDATION PROCESS MODEL MENINGKATKAN PROSOSIAL ANAK
}

\author{
Ummy Habibah \\ Pascasarjana UIN Sunan Kalijaga Yogyakarta \\ ummyhabibah94@gmail.com \\ Received : \\ ; Accepted : \\ ; Published :
}

\begin{abstract}
This journal is the result of research on family counseling through human validation process model to improve the low prosocial children in the family, so it could be a good attitude and behaviour. Reasearch method used qualitative approach with a case-study. This research sample is a child from a family. Instruments to collect the data are open-questionnaire, interviews and observation. This research results show that family counseling through human validation process model is given as a treatment is able tu increase prosocial's child in the family.
\end{abstract}

Keywords: family counseling (human validation process model), prosocial

Keluarga adalah wadah berkomunikasi yang paling intens dalam membangun kepribadian seorang anak. Beberapa hal yang mempengaruhi kepribadian seorang anak adalah sebagai berikut:

1. Macam dan kualitas hubungan antarpersonal, terutama antara orangtua dan anak;

2. Tingkat kualitas dan kuantitas hubungan antarpersonal dapat menghindarkan anak dari deprivasi;

3. Metode pengasuhan (parenting) dalam keluarga.

Menurut paparan diatas, kita dapat mengetahui bahwa kepribadian anak itu sangat dipengaruhi oleh keluarga. Dalam keluarga ada orang-orang yang memiliki kedekatan emosional dengan anak yang disebut dengan holding environment. Anak memiliki kedekatan emosional dengan orangtua atau dengan salah satu dari orangtua (ayah atau ibu). Ayah, ibu dan anak membentuk susunan nuclear family.

Dalam sebuah keluarga inti (nuclear family) yang terdiri dari ayah, ibu, dan anak. Keluarga adalah sebuah wadah terkecil dalam struktur atau tatanan kehidupan bersosial. Keluarga merupakan ladang pertama dimana individu mendapatkan hak-haknya sebagai manusia. Untuk memenuhi hak-haknya maka individu juga harus melakukan kewajibannya. Melihat fenomena yang terjadi banyak keluarga yang mengalami 
ketimpangan. Ketimpangan yang terjadi salah satunya diakibatkan oleh kurangnya komunikasi yang persuasif dalam keluarga. Hal tersebut menyebabkan tindakan yang dilakukan anggota keluarga, baik anak, ayah ataupun ibu tidak proporsional atau pemenuhan hak dan kewajiban sebagai anggota keluarga tidak dijalankan. Namun, ada pula yang sudah menjalankan kewajiban dan mendapatkan haknya, sehingga individu itu bisa membantu orang lain. Hal ini terjadi karena dalam keluarga, sejak kecil sudah diajari bagaimana bersikap demikian.

Fenomena yang sosial yang dikutip dari detik.com yang dilaporkan oleh Maya Safira menuturkan bahwa orang yang berkepribadian menolong dan tidak egois disebabkan adanya penanaman nilai semenjak usia dini. Kepribadian menolong tidak dapat muncul tanpa adanya nilai-nilai yang diajarkan orang tua kepada anak.

Dalam skripsi yang ditulis tahun 2012 oleh Maya Budi Indriani yang berjudul "perilaku prososial pada remaja ditinjau dari pola asuh demokratis", dapat diketahui bahwa keluarga sangat berperan dalam terciptanya perilaku prososial. Dalam penanaman sikap prososial maka sangat perlu dimulai sejak dini. Dengan penanaman nilai tolong menolong ini, maka keluarga dapat mengajarkan anak bagaimana bersosialisasi dengan baik dengan lingkungannya terutama dalam keluarga. Sehingga tidak dapat dihindari bahwa hal tersebut sangatlah penting. Maka perlu diketahui bahwa keluarga yang mendukung penanaman nilai akan membantu terbentuknya perilaku prososial.

Peneliti menemukan sebuah keluarga dengan fenomena anak yang hidup dalam sebuah keluarga yang kurang harmonis. Sebut saja namanya Dwi, dia anak kedua dari tiga orang bersaudara. Kakaknya sudah menikah di usia enam belas (16) tahun dan adiknya kelas tiga (3) SD. Dwi adalah seorang anak yang rentan putus sekolah, suka membolos dan kurang perhatian dari orangtuanya.

Konseli merasa apa pentingnya untuk berbuat sesuatu apabila tidak ada imbasnya untuk dirinya. Maka, Dwi masih rendah keinginannya untuk prososial dan konseli memerlukan dukungan dari keluarga. Keluarga yang mengajarkan kita untuk memiliki kepribadian yang baik dan mampu berbuat prososial. Sikap prososial adalah sikap yang akan tumbuh di dalam keluarga apabila sejak dini telah diajarkan untuk bersikap demikian. Sedangkan keluarga dari Dwi tidak mengajari dirinya untuk prososial dengan dirinya sendiri apalagi dengan lingkungan sekitarnya. Sehingga konseling keluarga sangat penting untuk dilakukan agar tercipta keseimbangan sehingga dapat meningkatkan prososial Dwi terhadap dirinya sendiri maupun dengan keluarga bahkan lingkungannya. 
Berangkat dari permasalahan ini, maka penulis mengangkat peningkatan prososial anak melalui proses konseling keluarga dan human validation process model dengan dipengaruhi komunikasi yang terjadi di didalam keluarga itu sendiri. maka tulisan ini diberi judul Konseling Keluarga Dengan Human Validation Process Model untuk Meningkatkan Prososial Anak.

\section{METODE}

Variabel $\mathrm{x}$ dari penelitian ini adalah konseling keluarga, sedangkan variabel $\mathrm{x}^{\wedge} 2$ ini adalah human validation process model serta variabel y adalah prososial anak. Penelitian ini mengunakan pendekatan kualitatif, yaitu penelitian yang dilakukan untuk memahami fenomena/kejadian yang dialami oleh subyek penelitian lebih dalam. Jenis penelitian ini berupa studi kasus yaitu studi mendalam pada sekelompok orang atau fenomena yang dideskriptifkan. Sebuah kasus terikat dengan waktu dan aktivitas, peneliti melakukan tahap pengumpulan data dalam waktu berkesinambungan.

Maka penelitian dengan pendekatan kualitatif dalam bentuk studi kasus, karena peneliti ingin memahami lebih dalam fenomena/kejadian yang dialami konseli dalam waktu tertentu untuk meningkatkan prososial. Dalam penelitian ini, teknik pengumpulan data digunakan untuk mengetahui seberapa peningkatan prososial anak dalam keluarga. Observasi dan wawancara yang dilakukan kepada konseli, keluarga, tetangga sebagai sumber data penelitian. Dokumentasi dilakukan untuk menggali gambaran umum dari proses kegiatan konseling yang dilakukan selama penelitian. Selain itu, penelitian ini juga menggunakan teknik analisis berupa analisis deskriptif komparatif. Analisis yang dilakukan adalah sebagai berikut:

a. Mendeskripsikan proses konseling keluarga dengan human validation process model dalam meningkatkan perilaku prososial anak dalam keluarga.

b. Mendeskripsikan keberhasilan konseling keluarga dengan human validation process model dalam meningkatkan perilaku prososial anak dalam keluarga

\section{HASIL}

Dwi adalah anak kedua dari hasil pernikahan Pak Wawan (nama samaran) dan Bu Titi (nama samaran). Dwi sempat putus sekolah dari sekolah lamanya yaitu SDN Pakis IX selama lebih kurang dua tahun. Dwi mengalami permasalahan perilaku prososial yang masih rendah dalam keluarga. Disaat pertemuan pertama peneliti dengan Dwi, dia sering menangis apabila orangtuanya menyuruh melakukan hal yang tidak sukainya. Dia susah untuk mengungkapkan keinginannya sehingga bibirnya bergetar-getar. Setelah 
didampingi beberapa bulan oleh peneliti dalam kegiatan CSR, akhirnya Dwi kembali bersekolah. Dwi kemudian berhasil dipindahkan ke sekolah baru di SDN Pakis VIII. Namun beberapa bulan terakhir ini, Dwi menjadi anak yang memberontak dan membuat orangtuanya bingung bagaimana menyikapi Dwi.

Selain itu, Dwi juga sering bolos sekolah dan lebih suka menghabiskan waktunya bermain gadget yang baru dibelikan orangtuanya dikamar. Dwi yang awalnya berinteraksi cukup baik menjadi anak yang kurang baik interaksinya dengan orangtua. Dia sering menolak untuk mengerjakan perintah orangtua tanpa ada imbalan yang didapatkannya. Sehingga perilaku prososial Dwi menurun dan interaksi yang dilakukan didalam keluarga menjadi interaksi yang tidak sehat. Interaksi yang tidak sehat dimulai dengan kurangnya komunikasi (keterbukaan dan kejujuran) antara anak dan orangtua. Sehingga untuk berperilaku prososial dibutuhkan beberapa tahap, supaya prososial yang terjadi antara anak dan orangtua meningkat kembali.

Perilaku prososial yang dibidik peneliti disini adalah sikap Dwi dengan orangtuanya. Bagaimana Dwi mencoba memenuhi permintaan orangtuanya tanpa menjadikan hal tersebut alasan untuk mendapatkan sesuatu yang bisa dijadikan alasan untuk tidak memenuhi harapan orangtuanya. Sedangkan dari deskripsi permasalahan ini, peneliti melihat perilaku Dwi belum menunjukkan bagaimana seorang anak seharusnya berperilaku prososial dalam keluarga. Dalam arti, Dwi belum bisa sepenuhnya mengerjakan sesuatu tanpa memperoleh sesuatu yang diinginkannya. Banyak sekali ayatayat Al-Qur'an yang memerintahkan bagaimana seharusnya kita bersikap kepada ibubapak. Tentunya perilaku prososial anak kepada orangtua dapat dibidik melalui bagaimana Dwi berperilaku kepada orangtuanya sehari-hari. Apakah menjadi anak yang penurut atau menjadi anak yang suka menjawab, memberontak, atau bahkan menjadi seseorang yang membenci orangtuanya sendiri.

Setelah melakukan beberapa kali pertemuan dalam melakukan identifikasi, diagnosis, prognosis kemudian penulis melakukan treatment. Peneliti yang bertindak sekaligus sebagai konselor kemudian menggunakan keluarga melalui beberapa tahap antara lain sebagai berikut:

1. Tahap pertama, dimana konselor saling sharing dengan konseli mengenai empati dengan keluarga sehingga komunikasi yang dilakukan bersifat efektif dalam keluarga terutama orangtuanya seperti bertuturkata yang santun, tidak memberontak, dsb. 
2. Tahap kedua, konselor melakukan konseling keluarga dengan orangtua konseli berupa open dicussion mengenai permasalahan yang ada dikeluarga. Orangtua konseli diarahkan untuk memaknai keluarga secara hakiki, apa yang menjadi harapan dan keinginan dibangunnya sebuah keluarga. Sehingga mereka menyadari peran mereka dalam keluarga, yang tidak lain adalah modelling perilaku untuk anakanak mereka. Selain itu juga, keluarga ini diberikan kontrak perubahan perilaku konseli dan orangtua.

3. Tahap ketiga, konselor melakukan konseling individu berupa sharing bersama Dwi. Dwi yang sudah mulai merasakan nyaman untuk bercerita dengan orangtua dalam artian sikap acuhnya sudah mulai berkurang. Orangtua Dwi juga sudah mulai memahami dan berperan sebagaimana mestinya. Tetangga konseli juga menuturkan bahwa interaksi keluarga juga sudah mulai baik, hal ini sudah terlihat dari pembicaraan antara Dwi dan orangtuanya.

4. Tahap terakhir, konseling keluarga dengan teknik sclupting dilakukan untuk memastikan sejauh manakah peningkatan perilaku prososial yang terjadi. Konseli sudah mulai jujur dan terbuka saat berbicara dihadapan orangtua. Orangtua pun begitu, tidak memaksakan keinginannya kepada konseli. Orangtua hanya menuturkan keinginan mereka tanpa memaksa konseli untuk memenuhi keinginan mereka. Keluarga sudah mulai mendidik anak mereka menjadi keturunan yang kuat. Artinya memiliki kejujuran dan keberanian untuk mengatakan kebenaran.

Setelah merealisasikan teknik/strategi konseling maka langkah selanjutnya adalah evaluasi untuk mengetahui sejauh mana efektifitas konseling dalam meningkatkan perilaku prososial konseli dalam keluarga.

Peneliti selanjutnya memprosentasekan data yang telah didapat setelah konseling:

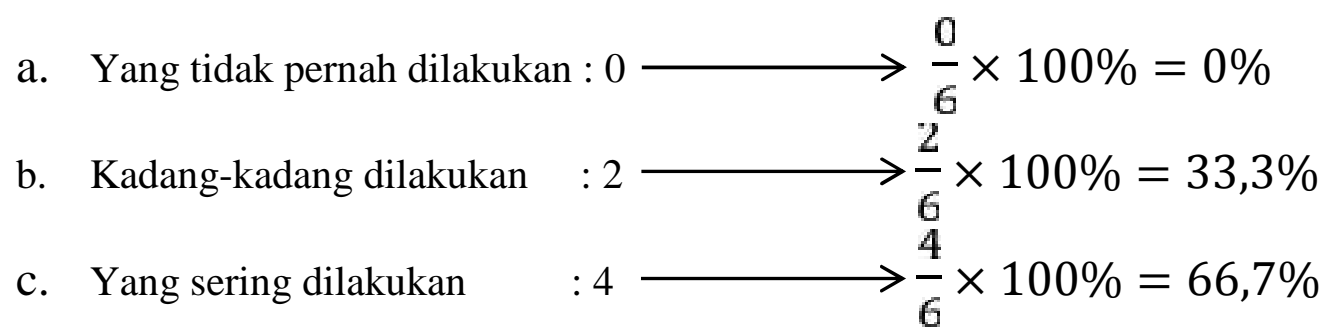

Dari prosentase diatas, dapat diketahui bahwa tingkat keberhasilan dari konseling keluarga dengan human validation process model dalam meningkatkan perilaku prososial anak adalah cukup berhasil berdasarkan standart uji antara 50\%-75\% yaitu $\pm 66,7 \%$. 
Teknik yang digunakan dalam konseling keluarga dengan human validation process model adalah family sclupting (keluarga mematung). Keluarga mematung digunakan untuk menghilangkan kecemasan konseli mengenai kebermaknaan mereka dan bagaimana mereka dalam pandangan orang lain dalam sebuah tatanan atau struktur keluarga. Selain family sclupting, dalam human validation process model juga terdapat teknik lain seperti family reconstruction. Namun, konselor tidak menggunakannya selama proses penelitian. Family reconstruction sudah dilakukan konselor sebelum adanya penelitian. Jadi, konselor melampirkan hasil dari family reconstruction yaitu berupa genogram (pemetaan keluarga).

\section{PEMBAHASAN}

\section{Konseling Keluarga}

Konseling keluarga telah berkembang pesat pada tahun 1970-an. Teknik konseling keluarga juga semakin inovatif. Pada saat sekarang ini, konseling keluarga lebih menekankan penanganan permasalahan-permasalahan konseling secara kontekstual daripada secara terpisah individu-individu. ${ }^{1}$ Samsul Munir Amin juga menyebutkan bahwa konseling keluarga adalah upaya pemberian bantuan kepada para individu sebagai pemimpin atau anggota keluarga agar mereka mampu menciptakan keluarga yang harmonis dan utuh, mengoptimalkan kemampuan diri dengan norma keluarga, serta berperan aktif dalam mencapai kehidupan keluarga yang bahagia. ${ }^{2}$ Hal tersebut dilakukan melalui pembenahan sistem keluarga agar potensi yang ada dalam keluarga tersebut berkembang dengan optimal dan masalahnya dapat diatasi atas dasar kemauan dan keinginan dari seluruh anggota keluarga berdasarkan kerelaan dan kecintaan terhadap keluarga. ${ }^{3}$ Konseling keluarga ini secara khusus berfokus kepada permasalahan yang berhubungan dengan situasi keluarga dan penyelenggaraannya melibatkan anggota keluarga. ${ }^{4}$

\section{Proses dan Tahapan Konseling Keluarga}

Pada awalnya seorang konseli datang kepada seorang konselor untuk mengkonsultasikan masalahnya. Biasanya, datang pertama kali ini lebih bersifat

\footnotetext{
${ }^{1}$ Achmad Juntika Nurihsan, Bimbingan dan Konseling: Dalam Berbagai Latar Kehidupan, (Bandung: Refika Aditama, 2014), hal. 102

${ }^{2}$ Samsul Munir Amin, Bimbingan dan Konseling Islam, (Jakarta: Amzah, 2013), hal. 66

${ }^{3}$ Kathryn Geldard \& David Geldard, Konseling Keluarga, (Yogyakarta: Pustaka Pelajar, 2011), hal. 13-14

${ }^{4}$ Latipun, Psikologi Konseling, (Malang: UMM Press, 2015), hal. 149 
“identifikasi pasien". Namun untuk tahap treat atau penanganan diperlukan kehadiran anggota keluarganya. Menurut Satir, tidak mungkin mendengarkan peran, status, nilai, dan norma keluarga apabila tidak ada kehadiran anggota keluarga. ${ }^{6}$ Jadi, pada proses konseling keluarga biasanya dimulai dengan mengidentifikasi konseli dan dilanjutkan dengan proses-proses yang selanjutnya. Sedangkan tahap yang terdapat di dalam konseling keluarga tidaklah berbeda dengan konseling pada umumnya, hanya saja teknik yang terdapat dalam kegiatan konseling akan berbeda.

\section{Human Validation Process Model}

Salah satu pendekatan dalam konseling keluarga adalah human procees validation model. Human validation process model yang dicetuskan oleh Virginia Satir (1916-1988) yang merupakan seorang terapis yang berfokus kepada perkembangan holistik yang sesuai dengan keperluan individu dan keluarga. Berikut adalah tabel mengenai human validation process model: ${ }^{7}$

Tabel 2.1 Tabel Human Validation Process Model

\begin{tabular}{l|l}
\hline Fokus & $\begin{array}{l}\text { Kebebasan memilih, perkembangan diri, membuat keputusan } \\
\text { pribadi dan pencapaian pribadi }\end{array}$ \\
\hline Tokoh & Virginia Satir \\
\hline Konsep dan Teori & Harga diri, komunikasi yang efektif \\
\hline Intervensi & $\begin{array}{l}\text { Membina komunikasi berkesan, mengatasi permasalahan dan } \\
\text { batasan perkembangan pribadi, perkembangan kesadaran diri, } \\
\text { terbuka dan spontan }\end{array}$ \\
\hline
\end{tabular}

Human validation process model fokus terhadap proses peningkatan dan validasi dari harga diri, aturan keluarga, dan keharmonisan pada pola komunikasi, membantu, dan memelihara keluarga triadi dan pemetaan keluarga, fakta kejadian kehidupan keluarga. Satir memandang akar permasalahan dari tiga generasi kehidupan. Satir juga memusatkan perhatian pada pola kehidupan yang akan datang, perkembangan pemetaan keluarga (genogram) dan fakta kejadian kehidupan. Untuk mengetahui keperluan itu, maka perlu ada komunikasi antar anggota keluarga dan orientasi humanistik mengupayakan harga diri dan penilaian diri seluruh anggota keluarga. ${ }^{8}$ Tujuan umum dan proses terapi adalah

\footnotetext{
${ }^{5}$ Samuel T. Gladding, Counseling: A Comperhensive Profession, (Canada: Pearson, 2013), hal 347

${ }^{6}$ Latipun, Psikologi Konseling, (Malang: UMM Press, 2015), hal. 156

Khoo Be Lee dan Mohd Hashim bin Othman, "Pendekatan Kaunseling Keluarga

Satir”. Pendidikan Kaunseling, 7 ( Januari, 2007), hal. 92

${ }^{8}$ Achmad Juntika Nurihsan, Bimbingan dan Konseling, (Bandung: Refika Aditama, 2014), hal. 10
} 
memfasilitasi keinginan perubahan dari sistem keluarga. Dan tujuan yang spesifik, yang berhubungan dengan proses perubahan: ${ }^{9}$

1. Meningkatkan harapan dan keberanian anggota keluarga untuk memformulasikan ide-ide baru

2. Mengakses, memperkuat, meningkatkan atau membangkitkan kemampuan menyontoh (coping) anggota keluarga

3. Semangat anggota keluarga untuk berlatih ide yang akan menghasilkan hal positif untuk membersihkan simptom-simptom belaka.

\section{Prososial}

Perilaku prososial ini tidak lepas dari kehidupan manusia dalam berinteraksi dengan lingkungannya. Interaksi yang dilakukan tidak lepas dari tolong menolong, karena dalam kenyataan hidup walaupun manusia dikatakan makhluk yang mandiri, namun pada saat tertentu manusia tetap membutuhkan pertolongan dari orang lain. Pertolongan yang didapatkan dari orang sekitarnya merupakan hasil interaksi sebagai upaya mempertahankan kelangsungan hidupnya. Apakah faktor yang mendorong seseorang untuk memliki perilaku menolong atau prososial. ${ }^{10}$ Myres menyatakan bahwa perilaku prososial adalah keinginan untuk membantu orang lain tanpa memikirkan kepentingan diri sendiri. ${ }^{11}$ Prosocial behavior diartikan sebagai tindakan apapun yang menguntungkan orang lain. ${ }^{12}$ Prososial adalah tindakan yang dilakukan ataupun direncanakan untuk menolong orang lain, tanpa memperdulikan motif-motif si penolong. Perilaku sosial berkisar antara tindakan altrusitik tanpa pamrih hingga tindakan menolong yang termotivasi dari diri sendiri. ${ }^{13}$ lebih jauh, perilaku prososial mencakup tindakan sharing, cooperative, donating, helping, honesty, generosity, serta mempertimbangkan hak dan kesejahteraan orang lain. ${ }^{14}$ Dalam penelitian ini, yang dibidik adalah perilaku prososial anak yang dapat mencakup sharing, helping, honesty yang dilakukannya dalam keluarga.

${ }^{9}$ Gerald Corey, Theory and Practice of Counseling and Psychoterapy: Sixth Edition, Fullurton: Thomsom Learning), hal 405 - 406

${ }^{10}$ Siti Mahmudah, Psikologi Sosial: Teori \& Model Penelitian, (Malang: UIN-Maliki Press, 2011), hal. 53

${ }^{11}$ Gusti Yuli Asih dan Margaretha Maria Shinta Pratiwi, "Perilaku Prososial Ditinjau Dari Empati dan Kematangan Emosi”, Jurnal Psikologi Universitas Muria Kudus, 1 ( Desember. 2010), hal. 34

${ }^{12}$ Robert A. Baron dan Donn Byrne, Psikologi Sosial, ( Jakarta: Erlangga, 2005), hal. 92

${ }^{13}$ Yeni Widyastuti, Psikologi Sosial, (Yogyakarta: Graha Ilmu, 2014), hal. 107

${ }^{14}$ Tri Dayaksini dan Hudaniah, Psikologi Sosial, (Malang: UMM Press, 2009), hal. 155 
a. Tahapan Perilaku Prososial

1) Tahap perhatian; Perhatian merupakan hal yang sangat penting dalam perilaku prososial. Hal ini disebabkan karena perilaku manusia banyak ditentukan oleh kemauan/kehendaknya.

2) Interpretasi situasi

Singkatnya, bagaimana individu menginterpretasikan kejadian yang

diperhatikannya. Dalam menginterpretasikan kejadian itu, ada dua macam hasil interpretasi yang muncul atau ditunjukkan:

a) Sesuatu yang perlu ditolong

b) Sesuatu yang tidak perlu ditolong

3) Tanggung jawab sosial (orang banyak)

Seseorang yang memiliki tanggung jawab sosial yang tinggi akan punya kecenderungan yang besar untuk menunjukkkan perilaku prososial. Seseorang mungkin akan dapat menolong orang yang dibencinya karena adanya rasa tanggung jawab sosial dalam diri individu tersebut.

4) Mengambil keputusan (menolong atau tidak)

Walaupun tadi sudah diputuskan untuk menolong, karena ada beberapa hambatan sebagai berikut: pengalaman-pengalaman terdahulu, dan sebagainya yang memungkinkan seseorang tidak jadi menolong. Oleh karena itu, sebenarnya pengambilan keputusan untuk menolong orang lain atau tidak sangat ditentukan juga oleh beberapa faktor intern maupun ekstern individu itu sendiri. ${ }^{15}$

Faktor Penentu Perilaku Prososial

1) Situasi sosial

Sears menyebutkan bahwa ada tiga hal yang mempengaruhi perilaku prososial seorang berkaitan dengan situasi ini, yaitu:

a) Kehadiran seseorang

b) Sifat lingkungan

c) Tekanan keterbatasan waktu referensi lain menganalisa tahapan perilaku prososial melalui skema sebagai berikut:

${ }^{15}$ Siti Mahmudah, Psikologi Sosial: Teori \& Model Penelitian, (Malang: UIN-Maliki Press, 2011), hal. 56 - 57 
Bagan 2.1 Bagan Tahapan Perilaku Prososial

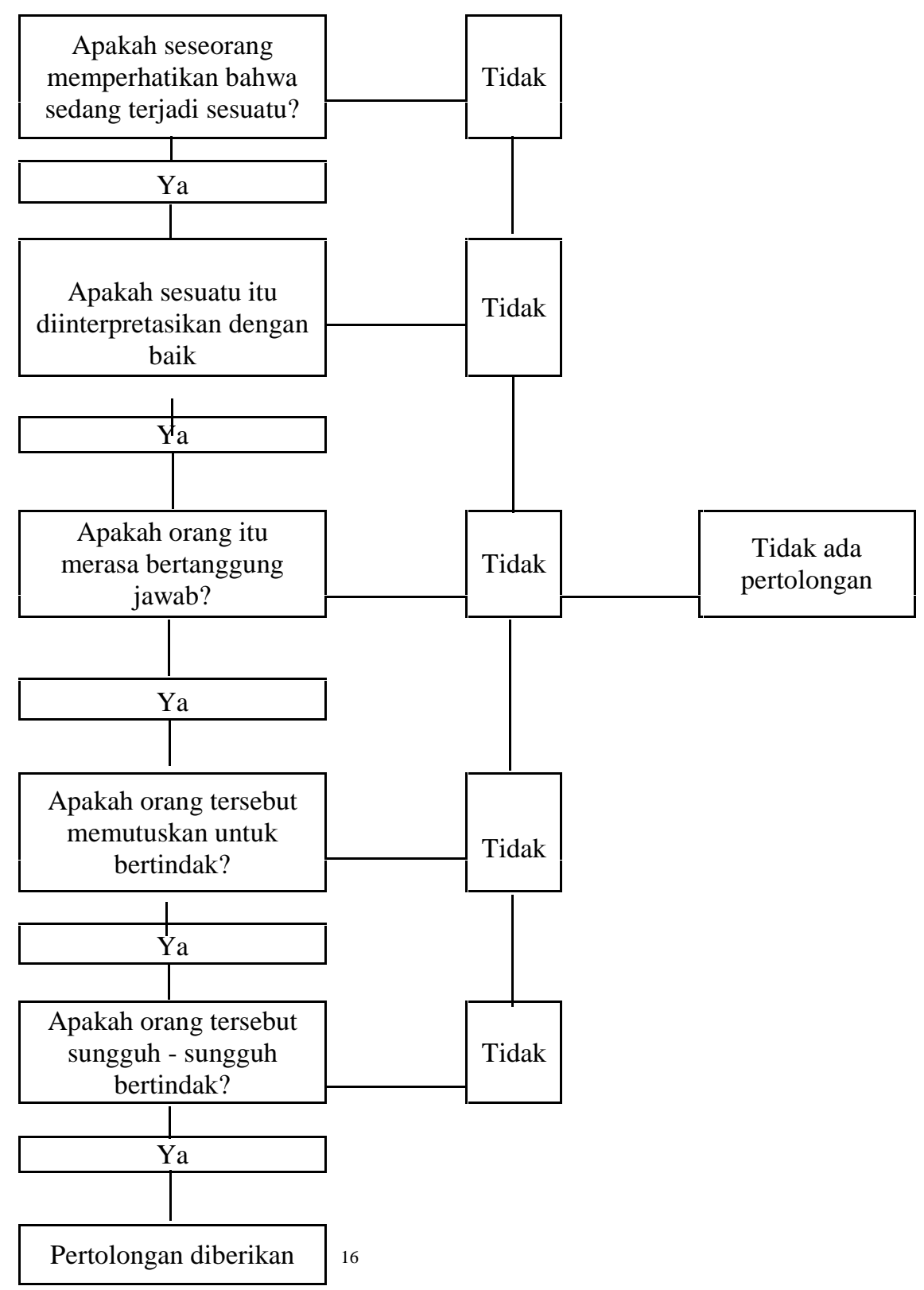

\section{KESIMPULAN}

Konselor melakukan langkah identifikasi, diagnosis, prognosis, terapi/treatment, dan evaluasi/follow up. Konselor memberikan bantuan kepada konseli melalui konseling keluarga yang berfokus pada salah satu pendekatannya yaitu human validation process model dengan menggunakan salah satu tekniknya yaitu family sclupting (keluarga

${ }^{16}$ Sarlito Wirawan, Psikologi Sosial, (Jakarta: Balai Pustaka, 2002), hal. 345 
mematung) untuk membentuk kelompok diskusi dalam keluarga tersebut. Konselor juga menggunakan kontrak perubahan melalui tabel perubahan agar dapat memantau perubahan sikap pada konseli seperti perubahan cara berkomunikasi dan hubungan yang baik dalam keluarga. Sehingga konseli bersedia memenuhi permintaan tanpa mengharapkan imbalan apapun bagi dirinya serta orangtua dan konseli saling membantu peningkatan prososial yang dilakukan konseli dalam keluarga baik terhadap orangtua, adik, dan sebagainya.

Konseli telah mengalami peningkatan dalam perubahan baik dari segi ucapan maupun tingkah laku. Konseli yang sering meminta imbalan saaat orangtua memintanya untuk mengerjakan sesuatu kemudian berubah lebih prososial (bekerja tanpa mengharap imbalan apapun). Konseli yang pada awalnya sering membentak, tidak jujur dan terbuka mengenai permasalahannya kepada orangtua, keluar rumah seizin tanpa orangtua, bersikap kurang sopan dalam kepada orang yang lebih tua dan tidak bertanggung jawab untuk mengerjakan tugas rumah serta konseli yang enggan untuk mendengar dan mengerjakan nasehat orangtua, kini sudah mulai berkurang. Hasil akhir dari proses konseling yang dilakukan dalam penelitian, dapat dikategorikan cukup berhasil dengan membawa hasil perubahan pada masing-masing anggota keluarga sesuai dengan permasalahan yang dihadapi oleh keluarga.

\section{DAFTAR PUSTAKA}

Amin, Samsul Munir. (2015). Bimbingan dan Konseling Islam. Jakarta: Amzah.

Asih, Gusti Yuli. dan Margaretha Maria Shinta Pratiwi. (2010) "Perilaku Prososial Ditinjau Dari Empati dan Kematangan Emosi”, Jurnal Psikologi Universitas Muria Kudus, 1 Desember.

Baron, Robert A. dan Donn Byrne. (2005) Psikologi Sosial. Jakarta: Erlangga.

Bungin, Burhan. (2011). Penelitian Kualitatif Komunikasi, Ekonomi, Kebijakan Publik, dan Ilmu Sosial Lainnya,. Jakarta: Kencana Prenada Media Group.

Chaplin, C. P. Kamus Psikologi. Jakarta: PT. Renika Cipta.

Corey, Gerald. Theory and Practice of Counseling and Psychoterapy: Sixth Edition. Fullurton: Thomsom Learning.

Dayakisni, Tri. dan Hudaniah. (2009). Psikologi Sosial. Malang: UMM Press.

Departemen Agama RI. (2006). Al-Qur'an dan Terjemahnya. Jawa Barat: CV. Diponegoro. 
Djamrah, Syaiful Bahri. (2004). Pola Komunikasi Orang Tua dan Anak Dalam Keluarga. Jakarta: Rineka Cipta.

Geldard, Kathryn. \& David Geldard. (2011). Konseling Keluarga. Yogyakarta: Pustaka Pelajar.

Gladding, Samuel T. Counseling: A Comperhensive Profession. Canada: Pearson.

Gunarsa, Singgih D. dan Yulia Singgih D. Gunarsa. (2004). Psikologi Perkembangan Anak dan Remaja. Jakarta: Gunung Mulia.

Indriani, Maya Budi. (2012). Perilaku Prososial Pada Remaja Ditinjau Dari Pola Asuh Demokratis. Skripsi. Fakultas Psikologi Universitas Katolik Soegijapranata Semarang. hal. Vii

Latipun. (2015).Psikologi Konseling. Malang: UMM Press.

Lee, Khoo Be. dan Mohd Hashim bin Othman. (2007). "Pendekatan Kaunseling Keluarga Satir", Pendidikan Kaunseling,

Lestari, Sri. (2012). Psikologi Keluarga. Jakarta: Kencana.

Mahmudah, Siti. (2011). Psikologi Sosial: Teori \& Model Penelitian. Malang: UINMaliki Press.

Mercer, Jenny. \& Debbie Clayton. (2012). Psikologi Sosial. Jakarta: Erlangga.

Nurihsan, Achmad Juntika. (2014). Bimbingan dan Konseling. Bandung: Refika Aditama.

Safira, Maya. "Berbagi Makanan Sejak Kecil Buat Orang Lebih Baik", detikFood. (online),http://www.search.detik.com/index.php?fa=detik.searchresult\&q uery=Prososial+keluarga\&area-id=news $\&$ siteid $=\& \mathrm{x}=0 \& \mathrm{y}-0$, diakses 11 November 2014

Widyastuti, Yeni. (2014). Psikologi Sosial. Yogyakarta: Graha Ilmu.

Willis, Sofyan S. (2013). Konseling Keluarga. Bandung: Alfabet.

Wirawan, Sarlito. (2002). Psikologi Sosial. Jakarta: Balai Pustaka. 